\title{
RESPON PETERNAK TERHADAP PEMANFAATAN EKSTRAK KULIT KAYU MANIS PADA DAGING BROILER
}

\author{
Muhammad Rifaldi, Kartika Ekasari Z, dan Andy \\ Politeknik Pembangunan Pertanian (Polbangtan) Gowa \\ e-mail: rifal7330@gmail.com
}

Received: 24 Agustus 2020; Accepted: 29 September 2020; Published: 25 Desember 2020

\begin{abstract}
ABSTRAK
Daging ayam broiler banyak diminati masyarakat disebabkan oleh teksturnya yang elastis, Warna dan aroma khas daging ayam broiler. Kulit kayu manis sangat efektif dalam menghambat pertumbuhan beberapa bakteri disebabkan oleh senyawa aktif seperti sinamaldehid dan asam sinnamat. Penelitian ini bertujuan untuk Mengetahui kualitas daging broiler dengan pemberian ekstrak kulit kayu manis. Manfaat dari penelitian ini yakni Memberikan informasi kepada Kelompok Wanita Tani (KWT) dan penulis tentang pemanfaatan ekstrak kulit kayu manis terhadap kualitas daging broiler. Penelitian dilaksanakan di kampus Polbangtan Gowa pada bulan maret sampai dengan april tahun 2018. penyuluhan dilakasanakan di Kelurahan Bontomanai, Kecamatan Bonto Marannu, Kabupaten Gowa, Provinsi Sulawesi Selatan. Metode penelitian yang dilaksanakan dengan menggunakan Rancangan acak lengkap (RAL) yang dilakukan terdiri dari 4 perlakuan dan 4 ulangan.Hasil menunjukkan bahwa ekstrak kulit kayu manis menunjukkan skor yang baik dari warna dengan skor warna yaitu pada P1 (5\%) dengan skor 80, tekstur yaitu pada P1 (5\%) dengan skor 84, dan aroma yaitu pada P3 (15\%) dengan skor 70,67. Hasil penyuluhan di kelompok tani responden mendapat respon positif. Perubahan pengetahuan diperoleh sebesar 235 (24,5\%), sikap 256 (26,7\%), dan keterampilan 271 (28,2\%).
\end{abstract}

Kata kunci: ekstrak kayu manis, daging ayam broiler, penyuluhan

\begin{abstract}
The aims of the study were to find out the quality of broiler chicken meat after given Cinnamon bark extract and to know the farmer response toward the material of the extension of the utilization of Cinnamon leaf extract to the quality of broiler chicken meat. The experiment was conducted at the Campus of Agricultural Extension Institute of Gowa and the extension was given to Women Farmer Group in Bontomanai Village, Bontomarannu District, Gowa Regency from March to April 2018. The study applied total random design (RAL) consisted of 4 treatments and 4 repetitions. The results of the study showed that the application of Cinnamon bark extract in P1 (5\%) gave better result in terms of meat color (score 80) and texture (score 85) while P3 gave better result to the meat flavor (score 70.76). The farmers' responses toward the extension ofthe utilization of Cinnamon bark extract was positive and showed the improvement of the farmer's knowledge for 235 (24.5\%), attitude for 256 (26.7\%), and skill for 271 (28.2\%).
\end{abstract}

Keywords: Cinnamon barks extract, broiler chicken meat, extension

\section{PENDAHULUAN}

Daging ayam broiler banyak diminati masyarakat disebabkan oleh teksturnya yang elastis, artinya jika ditekan dengan jari, daging dengan cepat akan kembali seperti semula. Jika ditekan daging tidak terlalu lembek dan tidak berair. Warna daging ayam segar adalah kekuningkuningan dengan aroma khas daging ayam broliler tidak amis tidak berlendir dan tidak menimbulkan bau busuk (Kasih dkk, 2012).

Daging memiliki kandungan gizi yang tinggi, lengkap, dan seimbang. Namun, kandungan

Diterbitkan Oleh, 
gizi yang tinggi pada daging merupakan media yang baik bagi pertumbuhan mikroba, sehingga daging merupakan salah satu bahan pangan yang mudah rusak atau perishable. Kerusakan pada daging dapat disebabkan karena adanya benturan fisik, perubahan kimia, dan aktivitas mikroba (Soeparno, 2005). Akibat dari kerusakan tersebut seperti pembentukan lendir, perubahan warna, perubahan bau, perubahan rasa dan terjadi ketengikan yang disebabkan pemecahan atau oksidasi lemak daging.

Bakteri yang mencemari daging baik yang mentah atau daging dengan proses pematangan yang kurang sempurna adalah Escherichia coli. Keberadaan bakteri ini dalam daging menunjukkan bahwa bahan pangan tersebut pernah tercemar oleh kotoran manusia ataupun hewan, sehingga dalam mikrobiologi pangan Escherichia coli disebut sebagai bakteri indikator sanitasi (Supardi dkk, 1999).

Tanaman kayu manis yang dikembangkan di Indonesia terutama adalah Cinnamomum burmanii Blume dengan daerah produksinya di Sumatera Barat dan Jambi dan produknya dikenal sebagai cassia-vera atau Korinjii cassia. Gupta dkk, (2008), menyatakan bahwa minyak atsiri kayu manis sangat efektif dalam menghambat pertumbuhan beberapa bakteri antara lain Bacillus cereus, Salmonella aureus, Ecercia coli $P$. aeruginosa dan Klebsiella sp. Penghambatan bakteri dengan minyak atsiri kayu manis ini disebabkan oleh senyawa aktif seperti sinamaldehid dan asam sinnamat.

\section{MATERI DAN METODE}

\section{Materi}

Alat yang digunakan adalah timbangan digital, pisau, kompor, panci, sendok, kain flannel/saringan, gelas ukur, wadah penyimpanan daging dan alat tulis menulis. Bahan yang digunakan yaitu daging ayam broiler bagian dada (didalam satu bagian dada lalu diambil 4 potong dengan masing-masing berat 100 gram, jadi untuk 16 potong dada dibutuhkan 4 ekor ayam), air untuk mencuci daging, air mineral 1,2 liter untuk pembuatan ekstrak dan kulit kayu manis sebanyak 120 gram.

\section{Metode}

Metode penelitian yang dilaksanakan dengan menggunakan Rancangan acak lengkap (RAL) yang dilakukan terdiri dari 4 perlakuan dan 4 ulangan.

Perlakuan yang diberikan dalam penelitian ini adalah sebagai berikut :

P0 : Tanpa pemberian eksrak kulit kayu manis (control)

P1 : Pemberian eksrak kulit kayu manis sebanyak $5 \%$

P2 : Pemberian eksrak kulit kayu manis sebanyak $10 \%$

P3 : Pemberian eksrak kulit kayu manis sebanyak $15 \%$

\section{Parameter}

\section{Warna daging}

Warna daging (Gambar 1) ayam segar adalah kekuning-kuningan (Kasih dkk, 2012). Warna daging broiler dilihat sebelum di berikan kulit kayu manis dan setelah pemberian serta penyimpanan.

\begin{tabular}{ccccc}
\hline 1 & 1 & 1 & 4 & \multicolumn{1}{l}{} \\
100 & 80 & 60 & 40 & 20
\end{tabular}

Keterangan, Putih Agak Kekuningan : 100; Putih Memudar : 80; Putih Kemerahan : 60; Putih Pucat Kemerahan : 40; Kemerahan : 20.

\section{Tekstur daging}

Teksturnya yang elastis, artinya jika ditekan dengan jari, daging dengan cepat akan kembali seperti semula. Jika ditekan daging tidak terlalu lembek dan tidak berair (Kasih dkk, 2012). tekstur daging broiler diperiksa dengan cara disentuh untuk mengertahui perbedaannya setelah diberikan kulit kayu manis dan setelah penyimpanan.

\begin{tabular}{ccccc}
\hline 1 & 1 & 60 & 40 & 20
\end{tabular}

Keterangan, Kenyal : 100; Agak Kenyal : 80; Agak Lembek : 60; Lembek : 40; Sangat Lembek : 20. 


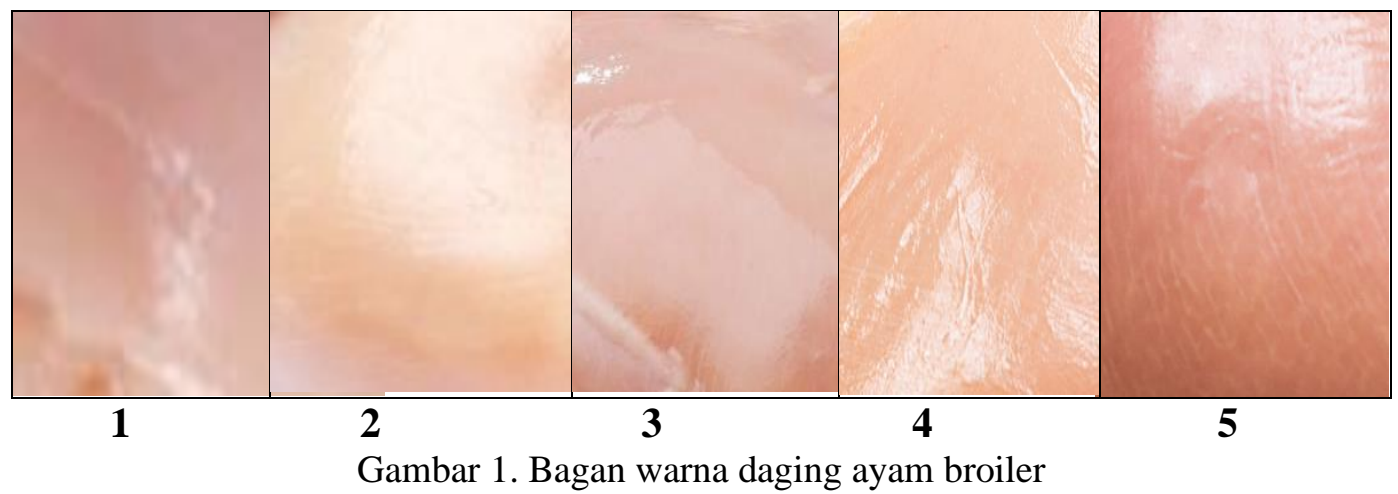

\section{Bau/aroma daging}

Aroma khas daging ayam broiler tidak amis tidak berlendir dan tidak menimbulkan bau busuk (Kasih dkk, 2012). aroma daging broiler dicium sebelum di berikan kulit kayu manis dan setelah pemberian serta penyimpanan.

\begin{tabular}{ccccc}
\hline 1 & 1 & 6 & 40 & 20
\end{tabular}

Keterangan, Tidak Amis : 100; Agak Amis : 80; Amis : 60; Busuk : 40; Sangat Busuk : 20.

\section{Tahapan Penelitian}

Tahap pembuatan ekstrak kulit kayu manis dengan metode infusa (Depkes, 2009).

1. kulit kayu manis dicuci bersih dan dipotong kasar

2. Direbus dengan $100 \mathrm{ml}$ air dalam panci, dipanaskan selama 15 menit terhitung saat air mulai mendidih, sambil sekali-sekali diaduk.

3. Setelah dingin, disaring menggunakan kain flannel dan ditambahkan air secukupnya sampai diperoleh kembali volume $100 \mathrm{ml}$.

4. kosentrasi $5 \%=5$ gram kulit kayu manis yang dengan air $100 \mathrm{ml}$ direbus selama 15 menit terhitung saat air mulai mendidih.

5. kosentrasi $10 \%=10$ gram kulit kayu manis dengan air $100 \mathrm{ml}$ direbus selama 15 menit terhitung saat air mulai mendidih.

6. kosentrasi $10 \%=10$ gram kulit kayu manis dengan air $100 \mathrm{ml}$ direbus selama 15 menit terhitung saat air mulai mendidih.

7. masukkan ke dalam wadah penyimpanan yang berisi sampel daging dada ayam broiler sampai sampel terendam seluruhnya dengan lama perendaman selama 60 menit.

8. Setelah direndam, sampel disimpan di suhu ruangan $\left(27^{\circ} \mathrm{C}\right)$ selama 12 jam lalu dilakukan pengujian

\section{Uji Organoleptik}

Uji organoleptik dilakukan menggunakan metode scoring (penilaian yang dilakukan panelis dengan skor)

1. Panelis yang digunakan sebanyak 15 orang.

2. Panelis disajikan sampel daging ayam 16 potong

3. Panelis diberikan kuesioner untuk menilai masing-masing daging ayam

Range nilai yang digunakan yaitu 1 sampai 3, nilai 1 untuk Mutu 3, nilai 2 untuk mutu 2, nilai 3 untuk mutu 1 daging ayam berdasarkan standar mutu daging ayam di Indonesia, lembar isian panelis dapat di lihat pada lampiran 3.

\section{Analisis Data}

Metode analisis data yang digunakan dalam penelitian ini yaitu data yang diperoleh diolah dengan sidik ragam sesuai dengan Rancangan Acak Lengkap (RAL) dengan bantuan microsoft exel dan software SPSS versi 16. Adapun model matematikanya (Gaspersz, 1991) adalah :

$$
Y i j=\mu+\tau i+\varepsilon i j
$$

Keterangan, $\mathrm{Yi}=$ Hasil pengamatan dari peubah pada penelitian ke-i dengan ke-j; $\mu=$ Rata-rata pengamatan $\tau \mathrm{i}=$ Pengaruh perlakuan ke-I; $\varepsilon \mathrm{ij}=$ Pengaruh galat percobaan dari perlakuan ke-i dan ulangan ke-j. 


\section{Evaluasi Desain Penyuluhan}

Evaluasi dilakukan untuk mengukur pengetahuan, sikap dan keterampilan Kelompok Wanita Tani (KWT) dalam pemanfaatan ekstrak kayu manis terhadap kualitas daging broiler. Evaluasi terdiri dari evaluasi awal dan evaluasi akhir. Metode yang digunakan untuk menganalisis tingkat respon peternak terhadap materi penyuluhan adalah dengan menggunakan skala likert kemudian ditabulasi dan digambarkan dalam bentuk garis continuum (Padmowiharjo, 2002).

Mengetahui tingkat pengetahuan, sikap dan keterampilan petani/peternak digunakan analisis diskriptif yaitu menggambarkan pengetahuan, sikap dan keterampilan dengan menggunakan data skala orginal (skala linkert) sedangkan alat ukur tingkat pengatahuan, sikap dan ketrampilan menggunakan Rating Scale. Adapun skornya yang digunakan adalah, skor 4 sangat mengetahui (SM), skor 3 mengetahui (M), skor 2 kurang mengetahui (KM) dan skor 1 tidak mengetahui TM).

Sampel yang diberikan kuisioner sebagai alat ukur dan analisis skala nilai (ranting scale) masing-masing sebanyak 10 pertanyaan untuk pengetahuan sikap dan keterampilan dimana seluruh pertanyaan tersebut terkait dengan judul. Hasil penilaian awal dan tes akhir diberi skor dengan ketentuan: jawaban (a nilai 4 , b nilai 3 , c nilai 2 , dan $\mathrm{d}$ nilai 1 ). sehingga interprestasi skor adalah skor tertinggi $24 \times 10 \times 4=960$ dan skor terendah $24 \times 10 \times 1=240$, menggunakan metode penunjukan langsung (Purposive sampling) dan digambarkan dalam garis continuum, yaitu Interval Kelas $=$ skor maksimum - skor minimum dibagi kriteria

Kuesioner yang digunakan terdiri dari pertanyaan untuk pengetahuan, pertanyaan untuk sikap yang terkait dengan judul. Untuk mengetahui efektifitas penyuluhan menggunakan kriteria presentase efektifitas digunakan rumus Ginting (1991),

$$
\mathrm{EP}=\frac{\mathrm{Ps}-\mathrm{Pr}}{\mathrm{N} 4 \mathrm{Q}-\mathrm{Pr}} \quad \mathrm{x} 100 \%
$$

Keterangan :

Ps $=$ Post test

Pr = Pree test

$\mathrm{N} \quad=$ Jumlah responden

$4=$ Nilai tertinggi

$\mathrm{Q}=$ Jumlah pertanyaan

$100 \%=$ Pengetahuan yang ingin dicapai

Ps-Pr = Peningkatan pengetahuan

$\mathrm{N} 4 \mathrm{Q}-\mathrm{Pr}=$ Nilai kesenjangan

Maka nilai persentase efektifitas tingkat pengetahuan adalah: $<32$ persen $=$ Kurang efektif; $32-64$ persen $=$ Cukup efektif; $>64$ persen $=$ Efektif

\section{HASIL DAN PEMBAHASAN}

\section{Uji Organoleptik}

\section{Warna daging broiler}

Berdasarkan hasil penelitian penggunaan kulit kayu manis (Cinnamomum burmanni) terhadap kualitas daging broiler menunjukkan bahwa pengaruh perlakuan terhadap warna memberikan pengaruh berbeda sangat nyata, pada rataan warna daging ayam broiler dari hasil perendaman selama 60 menit serta penyimpanan selama 12 jam. Dapat dilihat pada tabel 1.

Berdasarkan uji Duncan dapat terlihat bahwa perlakuan P1 memberikan hasil tertinggi = 80 dan berbeda nyata dengan perlakuan lainnya yaitu pada perlakuan $\mathrm{PO}=30.67, \mathrm{P} 2=57$ dan $\mathrm{P} 3=$ 54.67. Hasil analisis statistik dengan SPSS dapat dilihat pada lampiran 4. Dari hasil tersebut terlihat bahwa, pemberian ekstrak kulit kayu manis sebanyak 5\% menghasilkan skor warna yang relatif bagus dibandingkan dengan kontrol, Pada pemberian esktrak kulit kayu manis sebanyak $10 \%$ mulai menunjukkan penurunan skor warna daging, yaitu menjadi putih kemerahan dengan skoring 60 sesuai kriteria warna daging ayam broiler yang sudah ditetapkan beserta skoringnya dan sudah dinilai oleh beberapa panelis. Namun demikian, secara keseluruhan semua perlakuan yang diberikan ekstrak kulit kayu manis masih dalam kategori netral. Warna daging ayam segar adalah kekuning-kuningan (Kasih dkk, 2012).

Diterbitkan Oleh, 
Tabel 1. Rataan skor uji organoleptik dengan parameter warna daging ayam broiler selama penyimpanan 12 jam.

\begin{tabular}{cc}
\hline Perlakuan & Skoring Warna \\
\hline P0 & $30.67(\mathrm{a})$ \\
P1 & $80(\mathrm{~b})$ \\
P2 & $57(\mathrm{c})$ \\
P3 & $54.67(\mathrm{~d})$ \\
\hline
\end{tabular}

\section{Tekstur daging broiler}

Berdasarkan hasil kajia penggunaan kulit kayu manis (Cinnamomum burmanni) terhadap kualitas daging broiler menunjukkan bahwa pengaruh perlakuan terhadap tekstur memberikan pengaruh berbeda sangat nyata, pada rataan tekstur daging ayam broiler dari hasil perendaman selama 60 menit serta penyimpanan selama 12 jam.

Dapat dilihat pada tabel 2. Berdasarkan uji Duncan dapat terlihat bahwa perlakuan P1 memberikan hasil tertinggi $=84$ dan berbeda nyata dengan perlakuan lainnya yaitu pada perlakuan PO $=33.33, \mathrm{P} 2=76$ dan $\mathrm{P} 2=66.67$. Hasil analisis statistik dengan SPSS dapat dilihat pada lampiran 5. Hasil tersebut terlihat bahwa, pemberian ekstrak kulit kayu manis sebanyak 5\% menghasilkan skor tekstur yang relatif bagus dibandingkan dengan kontrol, Pada pemberian ekstrak kulit kayu manis sebanyak $10 \%$ mulai menunjukkan penurunan skor tekstur daging, yaitu menjadi agak lembek dengan skoring 60 sesuai kriteria warna daging ayam broiler yang sudah ditetapkan beserta skoringnya dan sudah dinilai oleh beberapa panelis. Namun demikian, secara keseluruhan semua perlakuan yang diberikan ekstrak kulit kayu manis masih dalam kategori netral. Teksturnya yang elastis, artinya jika ditekan dengan jari, daging dengan cepat akan kembali seperti semula. Jika ditekan daging tidak terlalu lembek dan tidak berair (Kasih dkk, 2012).

Tabel 2. Rataan skor uji organoleptik dengan parameter tekstur daging ayam broiler selama penyimpanan 12 jam.

\begin{tabular}{cc}
\hline Perlakuan & Skoring Tekstur \\
\hline P0 & $33.33(\mathrm{a})$ \\
P1 & $84(\mathrm{~b})$ \\
P2 & $76(\mathrm{c})$ \\
P3 & $66.67(\mathrm{~d})$ \\
\hline
\end{tabular}

\section{Aroma/bau daging broiler}

Berdasarkan hasil penelitian penggunaan kulit kayu manis (Cinnamomum burmanni) terhadap kualitas daging broiler menunjukkan bahwa pengaruh perlakuan terhadap Aroma/Bau memberikan pengaruh berbeda sangat nyata, pada rataan Aroma/Bau daging ayam broiler dari hasil perendaman selama 60 menit serta penyimpanan selama 12 jam. Dapat dilihat pada tabel 3.

Tabel 3. Rataan skor uji organoleptic dengan parameter Aroma/Bau daging ayam broiler selama penyimpanan 12 jam.

\begin{tabular}{cc}
\hline Perlakuan & Skoring Tekstur \\
\hline P0 & $36.00(\mathrm{a})$ \\
P1 & $68(\mathrm{~b})$ \\
P2 & $68(\mathrm{c})$ \\
P3 & $70.67(\mathrm{~d})$ \\
\hline
\end{tabular}

Diterbitkan Oleh, 
Berdasarkan uji Duncan dapat terlihat bahwa perlakuan P3 memberikan hasil tertinggi = 70.67 dan berbeda nyata dengan perlakuan lainnya yaitu pada perlakuan $\mathrm{PO}=36.00, \mathrm{P} 1=68$ dan $\mathrm{P} 2=$ 68. Hasil analisis statistik dengan SPSS dapat dilihat pada lampiran 6 .

hasil tersebut terlihat bahwa, pemberian ekstrak kulit kayu manis sebanyak $15 \%$ menghasilkan skor Aroma yang relatif bagus dibandingkan dengan kontrol, Pada pemberian ekstrak kulit kayu manis sebanyak 10\% mulai menunjukkan penurunan skor aroma daging, yaitu menjadi agak amis dengan skoring 80 sesuai kriteria aroma daging ayam broiler yang sudah ditetapkan beserta skoringnya dan sudah dinilai oleh beberapa panelis. Namun demikian, secara keseluruhan semua perlakuan yang diberikan ekstrak kulit kayu manis masih dalam kategori netral. Aroma khas daging ayam broiler tidak amis tidak berlendir dan tidak menimbulkan bau busuk (Kasih dkk, 2012)

\section{Pelaksanaan Evaluasi Penyuluhan}

Hasil evaluasi awal dan akhir ditabulasi untuk mengetahui tingkat pengetahuan sikap dan keterampilan wanita tani berdasarkan kategori penilaian yang dicapai. Hasil rekapitulasi dapat dilihat pada 4.

Tabel 4. Rekapitulasi hasil penilaian tingkat perubahan pengetahuan, sikap dan keterampilan Responden

\begin{tabular}{lcccccc}
\hline \multirow{2}{*}{ Uraian } & \multicolumn{2}{c}{ Pengetahuan } & \multicolumn{2}{c}{ Sikap } & \multicolumn{2}{c}{ Keterampilan } \\
\cline { 2 - 7 } & Jumlah & $\%$ & Jumlah & $\%$ & Jumlah & $\%$ \\
\hline Tes Awal & 523 & 54.4 & 521 & 54,2 & 512 & 53,3 \\
Tes Akhir & 758 & 78,9 & 777 & 80,9 & 783 & 81,5 \\
Perubahan Perilaku & 235 & 24,5 & 256 & 26,7 & 271 & 28,2 \\
\hline
\end{tabular}

Efektivitas Penyuluhan,

$$
\begin{aligned}
\mathrm{EP} & =\frac{\mathrm{Ps}-\mathrm{Pr}}{\mathrm{N} 4 \mathrm{Q}-\mathrm{Pr}} \times 100 \% \\
& =\frac{2.318-1.556}{(24.4 .30)-1.556} \times 100 \% \\
& =\frac{762}{1324} \times 100 \% \\
& =57.55 \%
\end{aligned}
$$

Kriteria penilaian yaitu sebagi berikut,

$<32$ persen

$32-64$ persen

$>64$ persen

$$
\begin{aligned}
& =\text { Kurang efektif } \\
& =\text { Cukup efektif } \\
& =\text { Efektif }
\end{aligned}
$$

Berdasarkan kriteria penilaian yang telah ditentukan, maka pelaksanaan penyuluhan yang telah dilakukan termasuk kategori cukup efektif yaitu 57,55 \%. Dengan adanya kegiatan penyuluhan maka diharapkan pengetahuan, sikap, dan keterampilan responden dapat ditingkatkan.

\section{KESIMPULAN}

Berdasarkan hasil penelitian dan penyuluhan, maka dapat diambil kesimpulan bahwa:

1. Berdasarkan uji organoleptik kualitas daging ayam broiler yang telah diberikan ekstrak kulit kayu manis menunjukkan skor yang baik dari warna dengan skor warna pada P1 (5\%) dengan skor 80 , tekstur pada P1 (5\%) dengan skor 84 , dan aroma pada P3 (15\%) dengan skor 70,67 yang menunjukkan bahwa kualitas daging masih baik setelah di simpan selama 12 jam pada suhu ruangan.

2. Hasil penyuluhan di kelompok tani responden mendapat respon positif. Perubahan pengetahuan diperoleh sebesar $235(24,5 \%)$, sikap $256(26,7 \%)$, dan ketrampilan 271 $(28,2 \%)$.

\section{DAFTAR PUSTAKA}

Abdullah, A, 1990. Kemungkinan Perkembangan Tiga Jenis Kayu Manis di Indonesia, dalam Tanaman Industri Lainnya. Prosiding Simposium I Hasil Penelitian dan Pengembangan 
Tanaman Industri, hal.1231-1244.

Anonim, 2006, Undang-Undang Nomor 16 Tahun tentang sistem penyuluhan pertanian, perikanan, dan kehutanan. Departemen pertanian, jakarta. , 2009. Farmakope Indonesia. Edisi IV. Departemen Kesehatan RI, Jakarta. 2009. Batas Maksimum Cemaran Mikroba Dalam Pangan. [SNI No. : 7388:2009].Jakarta.

2010. Ciri-ciri daging broiler. Keputusan Menteri Pertanian Republik Indonesia. [SNI No. : 01-42582010].Jakarta.

Djaafar, T.F. dan S. Rahayu. 2007. Cemaran mikroba pada produk pertanian, penyakit yang ditimbulkan dan pencegahannya. Jurnal Penelitian dan Pengembangan Pertanian 26(2): 67-75.

Erwin, 2012. Mengevaluasi Pelaksanaan Penyuluhan Pertanian. Bahan Diklat Sertifikasi Penyuluh Pertanian Level Supervisor. Bapeltan, Jambi.

Gaspersz, V. 1991. Metode Perancangan Percobaan. CV. Armico, Bandung.

Ginting, E. 1991. Metode Kuliah Kerja Lapang. Universitas Brawijaya, Malang

Gupta, Charu, Amar P. Garg, Ramesh C. Uniyal and Archana Kumari. 2008.Antimicrobial Activity of Some Herbal Oils Againts Common Foodborne Pathogens. African Journal of Microbiology.

Kasih, N, S. 2012. Pengaruh Lama Penyimpanan Daging Ayam Segar Dalam Refrigator Terhadap $p H$, Susut Masak, dan Organoleptik. Skripsi. Fakultas Pertanian. Universitas Islam Kalimantan Muhammad Aryad Al Banjary. Banjarmasin.

Leitasari, F. Y., 2012. Pengaruh Penambahan Ekstrak Jahe (Zingiber Officinale Rosc) Varietas Emprit Terhadap Aktivitas Antioksidan danAktivitasAntibakteri pada Telur Asin Selama Penyimpanan denganMetodePenggaraman Basah.
Ilmu dan Teknologi Pertanian. F. Pertanian. Universitas Sebelas Maret. Surakarta.

Mardikanto, 2009. Sistem Penyuluhan Pertanian. Lembaga Pengembangan

Pendidikan (LPP) UNS dan UPT Penerbitan dan Pencetakan UNS (UNS Press). Surakarta.

Padmowihardjo, S, 2002. Evaluasi Penyuluhan Pertanian, Modul Universitas Terbuka. Jakarta.

Prasetyaningrum, 2012. Aktivitas Antioksidan, Total Fenol, Dan Antibakteri Pada Minyak Atsiri Dan Oleoresin Kayu Manis (Cinnamomum Burmannii). Skripsi. Fakultas Pertanian, Universitas Sebelas Maret, Surakarta.

Sirait, J., Ira Sari, N., dan Leksono, T. 2017. Pengaruh Perbedaan Konsentrasi Dan Lama Perendaman Larutan Kulit Kayu Manis (Cinnamomum zeylanicu) Terhadap Daya Simpan Ikan Kembung (Rastrelliger kanagurta) Segar. Fakultas Perikanan dan Kelautan, Universitas Riau, Riau.

Soeparno, 2005. Ilmu dan Teknologi Daging. Edisi keempat. Gadjah Mada University Press. Yogyakarta.

Soputan, J. E. M. 2004. Dendeng Sapi Sebagai Alternatif Pengawetan Daging. Makalah pribadi Pengantar ke Falsafah Sains. Institut Pertanian Bogor. Bogor.

Stadelman, W.J., V.M. Olson, G.A. Shmwell, S. Pasch. 1988. Egg and Poultry Meat Processing. Ellis Haewood Ltd.

Suharyanto, 2008. Pengolahan Bahan Pangan Hasil Ternak. Jurusan Peternakan Fakultas Pertanian Universitas Bengkulu. Bengkulu.

Supardi, I., dan Sukamto. (1999). Mikrobiologi dalam Pengolahan dan Keamanan Pangan. Penerbit Alumni, Bandung.

Wijayanti, W., Agustina., Y. Zetra, dan P. Burhan. 2009. Minyak Atsiri Dari Kulit Batang Cinnamomum Burmannii (Kayu Manis) Dari Famili Lauraceae Sebagai Insektisida Alami, Antibakteri, Dan Antioksidan. Jurusan

Diterbitkan Oleh, 
Kimia Fakultas Matematika dan Ilmu Pengetahuan Alam. ITS. Surabaya.

Winarno, F. G., S. Fardias., dan D. Fardias. 1980.
Pengantar Pangan. Gramedia Pustaka Utama. Jakarta. 